\title{
Prevalence of Malaria Infection among People Living with HIV in Kinshasa
}

\author{
Erick Ntambwe Kamangu',2*, Hypolite Mavoko Muhindo ${ }^{3,4}$, Carole Weba Wapa-Kamangu ${ }^{2}$, \\ Hippolyte Nani-Tuma Situakibanza ${ }^{3,5}$ \\ ${ }^{1}$ Molecular Biology Unit, Department of Basic Sciences, Faculty of Medicine, University of Kinshasa, \\ Kinshasa, Democratic Republic of Congo \\ ${ }^{2}$ Research Group "Focus HIV/AIDS”, Kinshasa, Democratic Republic of Congo \\ ${ }^{3}$ Department of Tropical Medicine, Faculty of Medicine, University of Kinshasa, Kinshasa, Democratic Republic \\ of Congo \\ ${ }^{4}$ International Health Unit, University of Antwerp, Antwerp, Belgium \\ ${ }^{5}$ Department of Infectious Diseases, University Hospital of Kinshasa, Kinshasa, Democratic Republic of Congo \\ Email: ${ }^{*}$ Erick.kamangu@unikin.ac.cd
}

Received 22 January 2015; accepted 6 February 2015; published 12 February 2015

Copyright (C) 2015 by authors and OALib.

This work is licensed under the Creative Commons Attribution International License (CC BY).

http://creativecommons.org/licenses/by/4.0/

(c) (i) Open Access

\section{Abstract}

Background: Infection with the Human Immunodeficiency Virus (HIV) and malaria are two infectious diseases which are among the leading causes of morbidity and mortality in Sub-Saharan Africa and each a major public health problem. Data on malaria infection among people living with HIV (PLHIV) are poorly defined in Kinshasa as there are very few studies available on the subject. Objective: To determine the rate of co-infection HIV/malaria in Kinshasa to improve the care of PLHIV, this study was initiated to update the data. Methodology: This study was a prospective cohort. 123 volunteers participated in this study in the third month. 114 patients completed the 6month visit. Malaria diagnosis by microscopy was performed at the two medical visits. A sample of $5 \mathrm{ml}$ of blood was also drawn in a tube with EDTA for the determination of viral load and measuring the level of CD4 T cells. Results: In the third month of Antiretroviral Therapy (ART), we had 123 PLHIV (78 women and 45 men). Viral loads (VL) ranged from 390.79 copies/ml $\left(2.59 \log _{10}\right)$ and 38546691.53 copies $/ \mathrm{ml}\left(6.59 \log _{10}\right)$. The CD4 ranged between 90 and 547 cells $/ \mathrm{mm}^{3} .25$ patients $(20.33 \%)$ were positive for malaria. At 6 th month of ART, there were 114 patients $(75$ women and 39 men). The CV of the population ranged from 0 copies/ml and 2693671.54 copies $/ \mathrm{ml}(6.43$ $\left.\log _{10}\right)$. The CD4 at 6th month were in the range between 421 and 984 cells $/ \mathrm{mm}^{3} .20$ patients (17.54\%) presented positive thick smear for malaria. Conclusion: The prevalence rate of HIV/ malaria co-infection varies between $17.54 \%$ and $20.33 \%$ in Kinshasa.

\section{Keywords}

HIV, Malaria, Co-Infection, Kinshasa, Democratic Republic of Congo

${ }^{*}$ Corresponding author. 


\section{Introduction}

Infection with Human Immunodeficiency Virus (HIV) and malaria are among the leading causes of morbidity and mortality in Sub-Saharan Africa, and both are major public health issue [1]-[9]. Malaria and HIV infection share the same determinants of vulnerability to infection such as poor socio-economic conditions, illiteracy and under-informed society. Many of these conditions are met in Sub-Saharan Africa [3] [5] [7]. Thus, it is not surprising that malaria and HIV infection overlap geographically in many countries in this region due to the limited access to information, to education, health care services and means of prevention and treatment [3]-[9].

In addition, separate epidemiological data for these two infections are alarming in the Sub-Saharan African region. In this region, nearly 27 million cases of HIV in 2011, representing 67\% of global infections [1] [3]-[9]; about 207 million cases of malaria in 2012, roughly 81\% of global infections [2].

The Democratic Republic of Congo (DRC) is a country with low HIV seroprevalence $(<5.0 \%)$ [10]. In its epidemiological bulletin, the Ministry of Public Health reported 7,284,362 of malaria cases in 2009 with 15,685 deaths [11]. DRC is counted among the five most affected countries and totaling the highest number of deaths due to malaria in the world [2] [3]. Kinshasa is located in an area of high malaria endemicity but low HIV seroprevalence [2] [3]. Therefore, HIV-malaria co-infection is a current problem.

Data on malaria infection among people living with HIV (PLHIV) are poorly defined in Kinshasa as there are very few studies available on the subject [5]. This study was conducted to fill the gap on malaria-HIV co-infection in Kinshasa, DRC.

\section{Methodology}

\subsection{Study Design}

This was a prospective cohort study conducted in different Antiretroviral Treatment Centers (ATC) in Kinshasa. It took place from December 2012 to November 2013.

\subsection{Patients}

All patients living with HIV (PLHIV) and aged at least 18 years, regardless of sex, followed in the selected ATCs, having an up to date file and who consented were eligible. Pregnant women were not included. One hundred and twenty-three (123) volunteers participated in this study. They were recruited during their medical visit on the 3rd month of antiretroviral treatment follow up. They were followed in collaboration with the ATC until their 6th month visit for the second sampling. One hundred and fourteen (114) patients completed the 6-month visit. Nine (9) patients were missing from the ATC community services.

\subsection{Malaria Diagnosis and Blood Sampling}

Malaria diagnosis was performed by microscopy at months 3 and 6 medical visits. Thin and thick smears were performed from a finger prick. Staining was done with $10 \%$ Giemsa during $10 \mathrm{~min}$. The reading was done in duplicate using an ordinary microscope $1000 \times$ magnification (100× and $10 \times$ eyepiece lens). All samples were carried out by the technical staff of ATC.

\subsection{Viral Load and Blood Sampling}

A sample of $5 \mathrm{ml}$ of venous blood was also collected from the median vein in the elbow in a tube with EDTA anticoagulant for the determination of Viral Load (VL) [12] [13] and measuring the level of CD4 T-cell by FACS Count. CD4 counting was done routinely for all patients with a positive thick smear. Pairing by sex and age was done to determine other PLHIV for which we should measure CD4. The determination of VL was carried in the Molecular Biology Laboratory of the Medical School at the University of Kinshasa (UNIKIN). All VL were run in duplicate and only the mean values were used. 


\subsection{Ethical Considerations}

This study was approved by the Ethics Committee of the School of Public Health, University of Kinshasa (ESPUNIKIN) as well as the different ATC with whom we worked. The security and confidentiality of the patients were followed throughout the study.

\subsection{Data Analysis}

The statistical test Chi-square was used for qualitative variables and Student's t test for quantitative variables. The level of significance (p) was used for the probability of $\mathrm{p}<0.05$. The Mann-Whitney-Wilcoxon was used to compare data.

\section{Results}

Out of 123 PLHIV recruited on the 3rd month of Antiretroviral Therapy (ART), we have 78 women and 45 men, a sex ratio of 1.73:1. The age group most represented in our group was 31 to 40 years with $37.40 \%$ of the cases (Table 1). Viral Loads (VL) of the population ranged from 390.79 RNA copies/ml $\left(2.59 \log _{10}\right)$ to 38546691.53 RNA copies $\mathrm{ml}\left(6.59 \log _{10}\right)$ respectively minimum and maximum values with a median of 9837.65 RNA copies/ ml (3.99 $\log _{10}$ ) (Table 2 and Table 3). The CD4 ranged between 90 and 547 cells/ $\mathrm{mm}^{3}$ respectively minimum and maximum values, with a median of 356 cells $/ \mathrm{mm}^{3}$ (Table 2 and Table 4). A total of 25 (20.33\%) patients were positive for malaria, or $20.33 \%$ of co-infection on the 3rd month.

At 6 months of ART, 114 patients from the initial group returned, 92.68\% return turn-over. There were 75 women and 39 men, with a sex ratio of 1.92:1. The age group of 31 to 40 years was the most represented with $37.72 \%$ of cases (Table 1 ). The VL ranged from 0 RNA copies/ml (undetectable) to 2693671.54 RNA copies/ $\mathrm{ml}\left(6.43 \log _{10}\right)$ respectively minimum and maximum values, with a median of $892.85 \mathrm{RNA}$ copies/ml $\left(2.95 \log _{10}\right)$ (Table 2 and Table 3). The CD4 at 6 months were in the range between 201 and 984 cells/mm $\mathrm{mm}^{3}$ respectively minimum and maximum values, with a median of 451 cells $/ \mathrm{mm}^{3}$ (Table 2 and Table 4). A total of 20 (17.54\%) patients had positive TF for malaria, or $17.54 \%$ of co-infection at the 6th month.

Table 1. Age range (years).

\begin{tabular}{cccc}
\hline & Population M3 (123) & Population M6 (114) \\
\hline $\mathbf{1 8}-\mathbf{3 0}$ & 37 & 37 \\
$\mathbf{3 1}-\mathbf{4 0}$ & 46 & 43 \\
$\mathbf{4 1}-\mathbf{5 0}$ & 21 & 20 \\
$\mathbf{5 1}-\mathbf{6 0}$ & 12 & 11 \\
$>\mathbf{6 1}$ & 7 & 3 \\
\hline
\end{tabular}

Table 2. Population data.

\begin{tabular}{|c|c|c|}
\hline & Me (Min - Max) & $\%$ \\
\hline Age, years $(n=123)$ & $38(18-70)$ & \\
\hline \multicolumn{3}{|l|}{ Malaria at 3rd month $(n=123)$} \\
\hline - YES & & 20.3 \\
\hline - NO & & 79.7 \\
\hline Values of CD4 at 3rd month, cellules $/ \mathrm{mm}^{3}(\mathrm{n}=50)$ & $356(90-547)$ & \\
\hline Viral load at 3rd month, copies/ml (n = 123) & $9838(391-3,854,692)$ & \\
\hline \multicolumn{3}{|l|}{ Malaria at 6th month $(n=114)$} \\
\hline - YES & & 17.5 \\
\hline - NO & & 82.5 \\
\hline Values of CD4 at 6th month, cellules $/ \mathrm{mm}^{3}(\mathrm{n}=40)$ & $451(201-984)$ & \\
\hline Viral load at 6th month, copies/ml $(\mathrm{n}=114)$ & $893(156-2,693,672)$ & \\
\hline
\end{tabular}


Table 3. Values of viral load.

\begin{tabular}{lcc}
\hline & \multicolumn{1}{c}{ Viral Load (copies/ml) } & \\
\cline { 2 - 3 } & & Me (Min - Max) \\
\hline Malaria at 3rd month $(\mathbf{n}=\mathbf{1 2 3})$ & & $<0.001$ \\
- YES & $657,836(4909-3,854,692)$ & \\
- NO & $8543(390-987,649)$ & $<0.001$ \\
Malaria at 6th month $(\mathbf{n}=\mathbf{1 1 4})$ & & \\
- YES & $85,974(3753-2,693,672)$ & \\
- NO & $814(156-7426)$ & \\
\hline
\end{tabular}

Table 4. Values of CD4 (cellules/ $/ \mathrm{mm}^{3}$ ).

\begin{tabular}{|c|c|c|}
\hline & \multicolumn{2}{|c|}{ Values of CD4 (cellules/mm $\mathbf{m}^{3}$ ) } \\
\hline & Me (Min - Max) & $p$ \\
\hline Malaria at 3rd month $(n=50)$ & & 0.3 \\
\hline - YES & $309(90-500)$ & \\
\hline - NO & $356(95-547)$ & \\
\hline Malaria at 6th month $(n=40)$ & & $<0.001$ \\
\hline - YES & $366(201-522)$ & \\
\hline - NO & $601(421$ - 984) & \\
\hline
\end{tabular}

The results are presented as median $+/$ - Standard Deviation because the distribution does not meet the normal distribution.

All patients were taking first-line treatment according to the national program; 2 Nucleotide Inhibitor of the Reverse Transcriptase (Lamivudine and Zidovudine) and 1 Non-Nucleotide Inhibitor of the Reverse Transcriptase (Nevirapine or Efavirenz) [10].

\section{Discussion}

HIV infection and malaria are two diseases that affect the immune system. Their combination is commonly called a "cursed pair" [7]-[9]. HIV/malaria co-infection is a combination detrimental to the patient. One is the aggravating factor of the other and vice versa. The immunosuppression caused by the HIV infection makes the individual susceptible to recurrent episodes of severe malaria [5]-[9] [14] [15]. Malaria affects as well the immune system and induces a high viral replication, thus the presence of high VL in co-infected PLHIV [5]-[9] [14] [15].

In the third month of ART, the prevalence of co-infection HIV/malaria was $20.33 \%$. The median values of Viral Load (VL) are 730606.74 and 34781.40 RNA copies/ml (5.86 $\log _{10}$ and $4.54 \log _{10}$ ) respectively for the groups of HIV patients positive for malaria and those negative. The difference values of the VL are significant $(\mathrm{p}<0.001)$. The difference of VL in the 2 groups further confirms the involvement of malaria infection in viral proliferation as mentioned in literatures [5]-[9] [14] [15]. The median levels of CD4 are 310.69 and 355.80 cells/ $\mathrm{mm}^{3}$ for co-infected patients and the not-co-infected. The prevalence of HIV/malaria co-infection in the 3rd month is of $20.33 \%$ of co-infected patients.

At the 6th month of ART, the prevalence of co-infection HIV/Malaria was $17.54 \%$. The median VL values are 490890.36 and 1044.72 RNA copies/ml (5.69 $\log _{10}$ and $3.02 \log _{10}$ ) respectively for co-infected patients and not co-infected. The median levels of CD4 are respectively 369.65 and 629.45 cells $/ \mathrm{mm}^{3}$. The differences in VL values ( $\mathrm{p}<0.001)$ and CD4 ( $<0.001)$ were significant. At this stage of HIV infection, a patient on ARVs must retrieve a more or less normal immunological activity; thus non-co-infected CD4 high values at the 6th month for patients. At 6th month of ART, the rate of co-infection is $17.54 \%$.

The difference between the prevalence of HIV/malaria co-infection at M3 and M6 is not significant. Therefore, in our population, we have a co-infection rate in the range of $17.54 \%$ and $20.33 \%$. 
Previous work by Nyimi, M.L., et al. [16] reported in 2001 a HIV/malaria co-infection of $16 \%$ in a hospital institution in 24 patients with renal insufficiency. Kamangu, N.E., et al. [17] reported in 2012 a co-infection of $10.60 \%$ in PLHIV followed in a military hospital. In 1996, Situakibanza, et al. [18] found a rate of $40 \%$ for the co-infection HIV/malaria in HIV patients admitted for fever in a hospital institution. These figures differ because of modes recruitment of patients, institutions, and also periods of study. The higher rates reported by Situakibanza, et al. [18] could also be explained by the fact that the PLHIV in his study were not on ART and all had fever, one of the classic clinical expressions of malaria. However, the issue was presented as the geographic superposition of 2 epidemics causes a problem of co-infection in our region. Thus malaria diagnosis should be included routinely for PLHIV follow up in our region.

As the rate of co-infection at the 6th month of ART approaches the rate of treatment failure of ART reported in Kinshasa [19], it would be wise to systematize the search for an HIV/malaria co-infection before considering clinical treatment failure. If possible, a VL reassessment should be done 2 weeks later.

\section{Conclusion}

Currently, the prevalence of HIV/malaria co-infection varies between $17.54 \%$ and $20.33 \%$ in Kinshasa. This coinfection challenges the notion of antiretroviral therapy failure. Thus, it requires systematization of the malaria diagnosis at the 6th month visit to determine the implication of a possible co-infection before evaluating the treatment.

\section{References}

[1] UNAIDS (2012) Global Summary on the AIDS Epidemic.

[2] World Health Organization (WHO) (2013) World Malaria Report 2013. World Health Organization, Geneva.

[3] Organisation Mondiale de la Santé (OMS) (2004) Paludisme et VIH: Interactions et répercussions sur les politiques de santé publique. Rapport d'une consultation technique, Genève.

[4] UNAIDS/WHO. AIDS Epidemic Update December 2012.

[5] Skinner-Adams, T.S., McCarthy, J.S., Gardiner, D.L. and Andrews, K.T. (2008) HIV and Malaria Co-Infection: Interactions and Consequences of Chemotherapy. Trends in Parasitology, 24, 264-271. http://dx.doi.org/10.1016/j.pt.2008.03.008

[6] Rénia, L. and Potter, S.M. (2006) Co-Infection of Malaria with HIV: An Immunological Perspective. Parasite Immunology, 28, 589-595.

[7] Van Geertruyden, J.P. and D’Alessandro, U. (2007) Malaria and HIV—A Silent Alliance. Trends in Parasitology, 23, 465-467. http://dx.doi.org/10.1016/j.pt.2007.08.006

[8] Abu-Raddad, L.J., Patnaik, P. and Kublin, J.G. (2006) Dual Infection with HIV and Malaria Fuels the Spread of Both Diseases in Sub-Saharan Africa. Science, 314, 1603-1606. http://dx.doi.org/10.1126/science.1132338

[9] Aoussi, E.F., Tanon, K.A., Ehui, E., Ouattara, S.I., Inwoley, K.A., Adou-Bryn, K.D., Eholié, S.P. and Bissagnéné, E. (2011) Paludisme et infection à VIH en Afrique subsaharienne: Encore un couple maudit ? Sante, 21, 174-177.

[10] Programme National de la Lutte contre le Sida et les IST (PNLS), Ministère de la Santé Publique, République Démocratique du Congo. Rapport 2009. Avril 2010.

[11] Ministère de la Santé Publique, République Démocratique du Congo. Bulletin épidémiologique 2010, Mars 2011.

[12] Kamangu, N.E., Chatté, A., Boreux, R., Kalala, L.R., Mvumbi, L.G., Vaira, D. and Hayette, M.P. (2014) Mise en place d'une PCR Quantitative Temps Réel pour l'évaluation de la Charge Virale pour VIH à Kinshasa. Journal de Recheche BioMédicale, 1, 7-12.

[13] Kamangu, N.E., Chatte, A., Boreux, R., Kalala, L.R., Mvumbi, L.G., De Mol, P., Vaira, D. and Hayette, M.P. (2014) Implementation of an In-House Quantitative Real-Time PCR for Determination of HIV Viral Load in Kinshasa. Open Access Library Journal, 1, e855.

[14] Modia, A.O., Foidart, J.M. and Rigo, J. (2011) Influence de la co-infection paludéenne placentaire et VIH sur la biométrie et l’indice d'Apgar du nouveau-né à Kinshasa, République Démocratique du Congo. Journal de Gynécologie Obstétrique et Biologie de la Reproduction, 40, 460-464. http://dx.doi.org/10.1016/j.jgyn.2011.03.002

[15] Saracino, A., Nacarapa, E.A., da Costa Massinga, E.A., Martinelli, D., Scacchetti, M., de Oliveira, C., Antonich, A., Galloni, D., Ferro, J.J. and Macome, C.A. (2012) Prevalence and Clinical Features of HIV and Malaria Co-Infection in Hospitalized Adults in Beira, Mozambique. Malaria Journal, 11, 241. http://dx.doi.org/10.1186/1475-2875-11-241

[16] Nyimi, M.L., Lepira, B.F., Sumaili, K.E., Ebengo, B.C., Nseka, M.N. and Longo-Mbenza, B. (2001) Insuffisance 
rénale aïgue associée à l’infection par le VIH à Kinshasa: À propos de 24 observations. Louvain Médical, 120, 167172.

[17] Kamangu, N.E., Situakibanza, N.H., Mvumbi, L.G., Kakudji, I.L., Tshienda, T.D. and Mesia, K.G. (2012) Infections opportunistes chez les personnes vivant avec le VIH suivies à l’Hôpital Militaire de Référence de Kinshasa (Camp Kokolo). Revue Congolaise des Sciences, 1, 66-76.

[18] Situakibanza, N.H., Kapita, M.B., Mbendi, N., Odio, W., Mbula, M., Muvova, D., Mizerero, D. and Izzia, K. (1996) Etiologie de la fièvre au cours du SIDA: À propos de 64 cas. Panorama Medicale, 1, 842-845.

[19] Kamangu, N.E., Kawila, M.E., Mukumbi, H. and Mvumbi, L.G. (2012) Estimated Rates of Treatment Failure in First-Line Antiretroviral Treatment in Kinshasa: Case of the ACS AMO-Congo. International Journal of Collaborative Research on Internal Medicine and Public Health, 4, 885-891. 
Scientific Research Publishing (SCIRP) is one of the largest Open Access journal publishers. It is currently publishing more than 200 open access, online, peer-reviewed journals covering a wide range of academic disciplines. SCIRP serves the worldwide academic communities and contributes to the progress and application of science with its publication.

Other selected journals from SCIRP are listed as below. Submit your manuscript to us via either submit@scirp.org or Online Submission Portal.
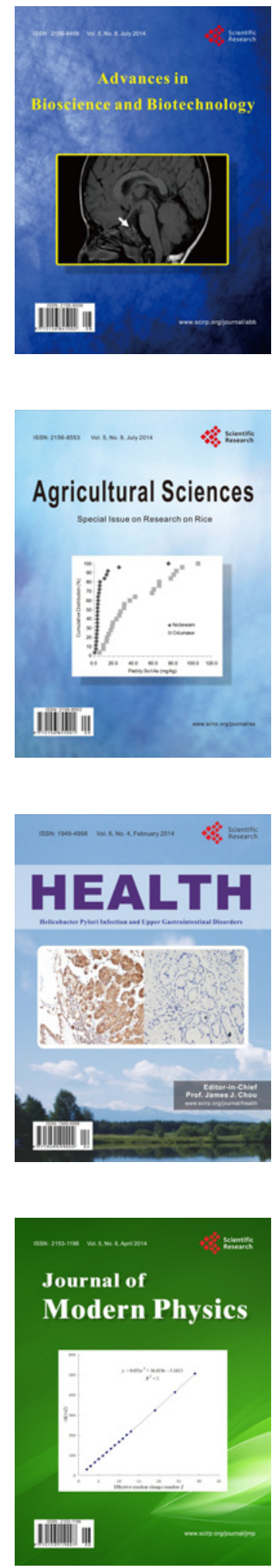
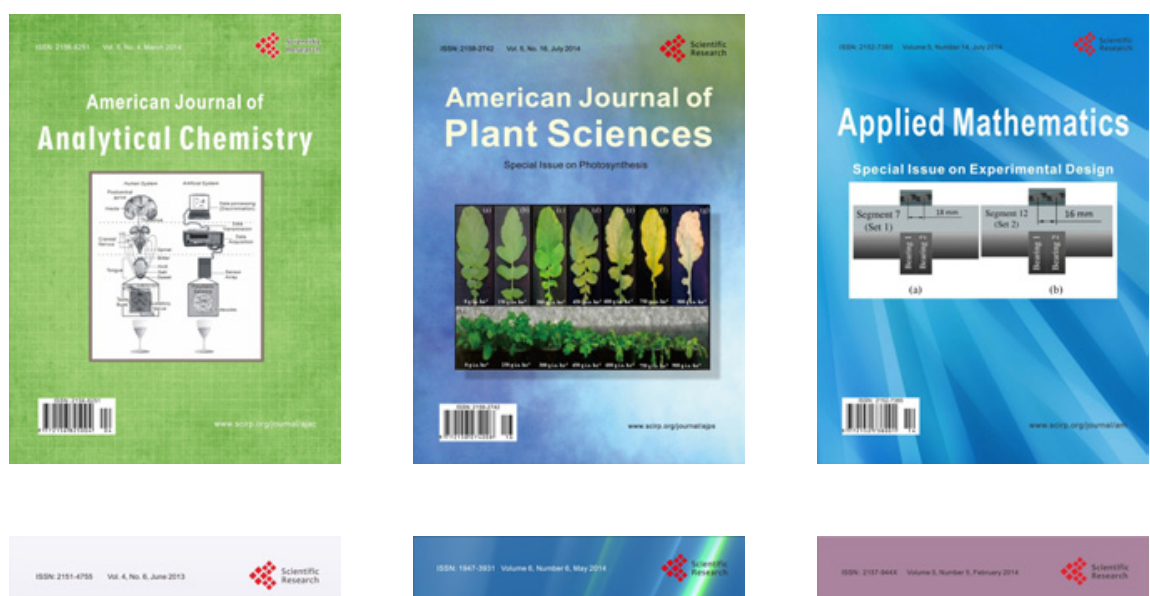

Creative Education
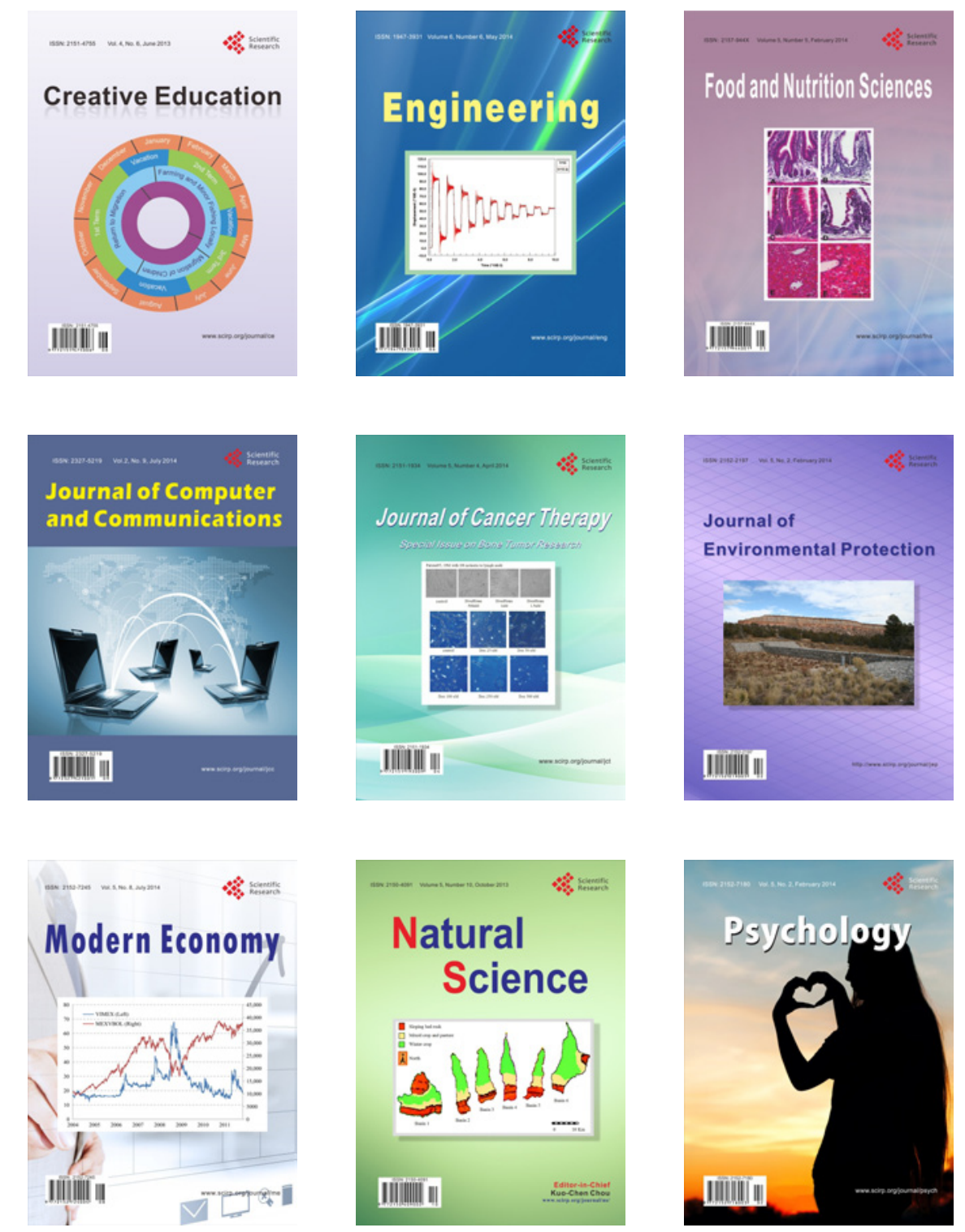